RESEARCH ARTICLE

\title{
Bacillus thuringiensis Isolated from Flour Mill Soil And Its Toxicity Against Culex And Aedes Larvae
}

\author{
Majekodunmi Racheal Adedayo \& Azeezat Ayodeji Uthman \\ Microbiology Unit, Biosciences and Biotechnology Department, Faculty of Pure and Applied Sciences, Kwara State \\ University, Malete, Nigeria
}

\begin{abstract}
Objectives: Entomotoxic microorganisms are becoming very effective as biocontrol agents in alternative to chemical formulations. This study aimed to evaluate isolation, characterization, and determination of the larvicidal activity of Bacillus thuringiensis against Culex and Aedes larvae.
\end{abstract}

Methods: Bacteria were isolated from soil samples collected from major flour mills in llorin metropolis. The isolates were screened biochemically to obtain B. thuringiensis, which isolated were further subjected to molecular characterization. Larva toxicity was determined against Culex and Aedes larvae using standard procedure. Four densities of bacilli load were prepared using the McFarland turbidity standard $0.5,1,2$, and 3 , and the time range was $0-48$ hours.

Results: Five isolates were obtained and named BT1, BT2, BT3, BT4, and BT5. All the isolates were toxic to the larvae tested. Bacillus thuringiensis isolated appears to be more toxic to Aedes larva than Culex larva. The most effective isolate was BT5, with a more than $65 \%$ mortality percentage. The percentage occurrence of Bacillus thuringiensis among the isolates is 62.5\%. Crystal (Cry) 1 and 2 protein gene occurs in 100 and $80 \%$ of the isolates, respectively.

Conclusion: Formulations of $B$. thuringiensis from the isolates could serve as a form of biopesticide on mosquitoes and consequently control malaria and other mosquito-borne diseases of global health concern. J Microbiol Infect Dis 2021; 11(4):224-232.

Keywords: Biopesticide, Larvae, Toxicity, Bacillus thuringiensis, Aedes, Culex

\section{INTRODUCTION}

The menace of recurrent mosquito-borne diseases in epidemic proportions has become a major medical concern globally. However, the environmental challenge of chemical control of the vector is deleterious [1,2]. Hence, emphasis is recently shifted to ecofriendly and economically viable means of curtailing the insect [2,3]. Therefore, it has become essential to develop environmentally friendly biological control against agents of vector-borne diseases all over the globe. Mosquito, especially Aedes and Culex species, transmit many crucial diseases such as malaria, filariasis, and encephalitis [2,4].
There have been several chemosynthetic pesticidal agents formulated and are in use. However, chemosynthetic pesticide applications have caused many health and environmental problems, including insect resistance and toxicity to humans, destruction of micro soil fauna and some beneficial insects, and accumulation in crops $[5,4,6]$. An alternative approach for mosquito control is the use of natural products from plants and microorganisms [2]

Most synthetic chemical agents were reported to invariably get into rivers and other water bodies through floods and run-offs [4]. Subsequently, this leads to increased resistance and resurgence of pest and pestborne diseases [5,6]. Globally efforts have

Correspondence: Majekodunmi Racheal Adedayo, Microbiology Unit, Biosciences and Biotechnology Department, Faculty of Pure and Applied Sciences, Kwara State University, Malete, Nigeria

E-mail: majekodunmi.adedayo@kwasu.edu.ng

Received: 08 April 2021 Accepted: 20 November 2021

Copyright (C) JMID / Journal of Microbiology and Infectious Diseases 2021, All rights reserved 
been directed at controlling these problems through biopesticide alternatives [3]. Microbial insecticides are more relevant in pest management because they are strain-specific [2]. Mosquito control involves different means to mitigate mosquito growth and suppress the spread of mosquito-borne diseases [7]. The control can be achieved by controlling the mosquito larvae, adult, and or breeding habitat modification. The most efficient of these is larvae control $[8,9]$. According to a previous study [7], one safe agent for controlling anopheline larvae is Bacillus sphaericus. Bacillus thuringiensis is a known alternative to chemical compounds for vector control. This soil bacterium has been commonly used as a biopesticide for decades. Due to its high insect toxicity and specificity, it reportedly constitutes about $95 \%$ of most commercial bioinsecticides. It is also a safe and highly effective broad-spectrum control of human disease vectors and agriculture pests [2,4].

Bacillus thuringiensis (Bt) is a Gram-positive, rod-shaped, spore-forming, soil-dwelling bacterium commonly used as a biological pesticide. They grow at environmental temperature and are ubiquitous all over the globe [2,10]. They are also found in abundance in the gut of some butterfly larvae and grains and mill soil [10]. Bacillus thuringiensis is a known producer of toxic proteins with insecticidal action $[2,4]$. Although, not all strain possesses insecticidal potential [4]. Molecular studies showed that Bacillus thuringiensis carries a crystalline (Cry) protein inclusion known to be majorly responsible for its entomotoxicity. Besides the Cry toxins, Bacillus thuringiensis reportedly contains other virulence factors $[2,10]$ such as $\beta$-exotoxins, aexotoxins, hemolysins, enterotoxins, chitinases, and phospholipases

Using indigenous products from Bacillus spp. is highly desirable as it would build a local capability to produce biopesticide in developing countries. This would suppress dependency on imported products and activate local biopesticide production [7]. However, there is the need to identify novel and more active strains of the bacterium with insecticidal activity on pests of crops. However, there is an information gap on the prevalence of environmentally relevant $B$. thuringiensis in Kwara State and its potential to be used as a biopesticide. Therefore, studies on an indigenous isolate of $\mathrm{B}$. thuringiensis are essential from public health and economic perspectives. Hence, this research aims to isolate, characterize, and determine the larvicidal activity of Bacillus thuringiensis from local flour mills in Ilorin, Kwara State.

\section{METHODS}

Soil samples were collected from six local flour mills at llorin, the west local government of Kwara State, Nigeria. The samples were collected by scraping off the soil surface with a sterile spatula and obtaining approximately $200 \mathrm{~g}$ from a depth of about one inch below the surface. These samples were kept in sterile polythene bags and taken to the laboratory immediately for analysis. The temperature of the sites was taken with mercury in a glass thermometer, and the $\mathrm{pH}$ of the samples was taken in the laboratory with an electrode $\mathrm{pH}$ meter (PHF-3C). The moisture content of the samples was also taken.

\section{Isolation of Microorganisms from Soil Samples}

Isolation of Bacillus thuringiensis was carried out according to the method described by [11]. One Gram of soil sample was suspended in 9 $\mathrm{ml}$ of sterile distilled water and mixed vigorously by vortexing. Ten-fold serial dilutions with sterile distilled water were done before plating on Nutrient Agar (NA). Bacillus thuringiensis-like colonies are usually creamcolored, white, large, nearly circular with acceptable irregular margins, and maybe glossy, less glossy, or rough. They have the appearance of a fried egg on a plate [2,4] were selected and sub-cultured to get pure culture. It was maintained on slants at $4 \mathrm{OC}$ for further use.

\section{Morphological and Biochemical characteristics}

Eight isolates were selected for further characterization based on colonial morphology using critical morphological/ physiological/ biochemical tests such as Gram's reaction, catalase, oxidase, indole, citrate utilization, and starch hydrolysis were performed as described by $[12,13]$.

\section{Screening for Sporulation in Isolates}

A sodium acetate selection test was carried out for all the eight organisms selected. A sample of each isolate was heat-shocked at 80 ${ }^{0} \mathrm{C}$ in a water bath for 10 mins to eliminate any 
vegetative cells. The resultant spore mixture was cultured on T3 media (per liter: $3 \mathrm{~g}$ tryptone, $2 \mathrm{~g}$ tryptose, $1.5 \mathrm{~g}$ yeast extract, 0.05 $\mathrm{M}$ sodium phosphate, $0.05 \mathrm{~g}$ magnesium chloride) made up with $0.06 \mathrm{M}$ concentration of sodium acetate and incubated for 24 hours at $30{ }^{\circ} \mathrm{C}$ to obtain single colonies. This medium also partially inhibits the growth cycle and sporulation of other Bacillus species. This test provides a preliminary assumption that the isolates were Bacillus thuringiensis, depending on the result obtained [14].

\section{Larva Toxicity Bioassays}

The toxicity of the five isolates that grew on T3 media was carried out on larvae of Aedes and Culex mosquitoes. All strains of Bacillus thuringiensis isolated were maintained/grown in sporulation medium/agar (per liter: $10 \mathrm{~g}$ of tryptone, $5 \mathrm{~g}$ of yeast extract, $5 \mathrm{~g}$ of sodium chloride, and $15 \mathrm{~g}$ of agar) for 48 hours at 30 ${ }^{0} \mathrm{C}$. Four densities were prepared using the McFarland turbidity standard (Standards number $0.5,1,2$, and 3) [23]. To prepare 0.5 standard, $99.5 \% \mathrm{BaCl}$ was added to $0.5 \%$ $\mathrm{H} 2 \mathrm{SO} 4)$. Each standard was added to a 250 $\mathrm{ml}$ conical flask with $100 \mathrm{ml}$ of distilled water and 25 larvae as test organisms. The conical flask containing distilled water and the test organisms without Bacillus thuringiensis was used as the negative control. The test was done in triplicate. After a 48-hour of observation, the number of dead larvae was recorded. A mortality count of more than $50 \%$ of the larvae after 48 hours of observation was considered toxic [15].

The entomotoxic activity of each of the five isolates was evaluated after four (4) hours which is the minimum hour of observation. The mortality rate of the earliest hours of observation was considered to assess the severity of the toxicity. Comparison between toxicity to Culex and toxicity to Aedes larvae was also determined [15]. The mortality rate and the percentage occurrence of Bacillus thuringiensis among the isolates were calculated. The mean value and the standard error of mean were also calculated with $P$ $<0.01$.

\section{Molecular Characterization}

All the five isolates used for larva toxicity bioassay were subjected to molecular characterization as follows: Overnight culture of entomotoxic isolates was prepared in nutrient broth. The broth culture was used for DNA extraction and PCR amplification as described by [16]. PCR amplification assay reagents were purchased from Bioline, Taunton, USA, and Invitrogen Corporation, USA. The sequencing results were generated from the ABI Prism $3130 \times 1$ Genetic automated sequencer (Applied Biosystems) and were carefully edited, filtered, and assembled for polymorphism detection using BioEdit software [16].

\section{Phylogenetic Tree Reconstruction of Five Isolates Amplified and Sequenced With 165 RNA Marker}

Sequence similarity searches were compared with GeneBank databases using BLAST (Basic Local Alignment Search Tool). Multiple alignments were done using the ClustalW. Phylogenetic trees were constructed using the Maximum Likelihood Method [16].

\section{Identification of Cry Protein Gene}

Nucleotide sequences of Cry genes available from GenBank were aligned using the Megalign program of the DNAStar software package. Two highly conserved regions among all crystal genes were selected, and two 20-mer 5'-degenerate primers were designed to match any known Cry genes. By use of a similar computer analysis or type primers (i.e., primers specific to a given type of crystal gene), were designed to match the hypervariable region of Cry 1 specifically, Cry 2, Cry 3, Cry 4, Cry 7, Cry 9, and Cry 11 [17].

\section{Statistical Analysis}

Statistical analysis was carried out on the toxicity test result using Analysis of Variance to analyze the data. In contrast, SPSS was used to find the mean, and standard error mean (SEM) of the $\mathrm{pH}$, temperature, and moisture content.

\section{RESULTS}

A total of eight bacteria consisting of both Gram-positive and Gram-negative bacilli selected based on colonial morphology and colors was biochemically characterized to four genera: Bacillus (5), Klebsiella (1), Salmonella (1), and Staphylococcus (1). The detail of the biochemical characteristics is presented in Table 1. Based on the biochemical characteristics, eight isolates were selected for further screening. 


\section{Sporulation and ability to grow on T3 agar to suspect Bacillus thuringiensis}

Five of the eight isolates that showed positive results by growing T3 media were used for further analysis and toxicity tests.

\section{Toxicity of Bacillus thuringiensis against Aedes and Culex Mosquito Larvae}

The result of the toxicity test is shown in Tables 2 and 3. Bacillus thuringiensis appears to be more toxic to Aedes larva than Culex larva. The number of dead larvae recorded after 4 hours (the minimum hour of observation) and after 48 hours are presented. According to the result, the most effective isolates against the tested larvae was the BT5, with a mortality percentage of more than $65 \%$. The percentage occurrence of Bacillus thuringiensis among the isolates is $62.5 \%$.

\section{Gel Electrophoresis Result}

The result of the gel electrophoresis is shown in Figure 1. It was photographed on UV Transilluminator light. Based on the 16S rRNA gene sequence, Bacillus $\mathrm{sp}$. was identified as Bacillus thuringiensis. The DNA sequences were aligned, and a phylogenetic tree was constructed by the neighbor-joining method using MEGA5.01 (Fig. 2). Nucleotide sequence analysis of the isolates using the clustalW program revealed that the isolate showed homology with Bacillus thuringiensis. Isolates 2, 8, 3, 7, and 5 were identified as BT1, BT2, BT3, BT4, and BT5, respectively.

\section{PCR-Based Detection of Cry Genes in Bacillus thuringiensis Isolates}

Each set of the primers produced a PCR product with a unique molecular weight showing the presence of one or more crystal genes. Strains harboring crystal 1, 2, and 11 genes were found at 100,80 , and $40 \%$ frequencies, respectively (Table 4). Frequencies of strains harboring Cry 3, 4 were $60 \%$ each. As a result, isolates containing Cry 1 and 2 genes were the most abundant compared with isolates containing other Cry genes, and the least common Cry genes were Cry 7 and 9. In addition, it was observed that some of the isolates harbored two or more Cry genes.

\section{DISCUSSION}

The soil environment has been reported to be the wealthiest and most supporting habitat for microbes. Different microbes have been isolated from the soil, such as Salmonella spp., E. coli, Klebsiella spp., and Bacillus spp. [18]. The geographical distribution of Bacillus thuringiensis in soil habitats has been well documented $[2,3,4,19]$. In many countries, the bacterium existed naturally in soil environments, grains, natural grain silos, leaf litters, and stored product dust [21-22]. [23,24] reported that Bacillus thuringiensis is more abundant in stored product environments than other soil. This bacterium is a chemoheterotroph depending on organic carbon could be responsible for its association with grains, grain dust, and flour mills [10,24].

Since discovering its potential and effectiveness as a biological control agent, Bacillus thuringiensis has been isolated in various parts of the world and from a wide variety of substrates such as maize, sorghum, and wheat [25-27]. In this study, Bacillus thuringiensis was isolated from local flour mill soil. This finding is in support of the claim by [10] that the bacterium can be found in flour mill soil. This observation could be due to the abundance of grain dust in the flour mill soil since soil properties could affect the abundance and distribution of Bacillus thuringiensis $[11,20,28]$. Bacillus thuringiensis to survive in several locations might be attributed to its spore production potential [2], which enables it to survive the adverse conditions of alternating wetness and dryness associated with the soil environment. Also, it is chemoheterotrophic and most likely carries amylolytic enzymes that could break down grain flour for their metabolism.

The colonial, cellular, and biochemical characteristics of the Bacillus thuringiensis isolated were similar to the report of earlier authors $[10,29]$. In addition, recent reports on the frequency of Bacillus thuringiensis isolates from natural environments indicate a high probability of isolating a novel strain with insecticidal potential [23].

In this study, Bacillus thuringiensis isolated proves to be toxic to both Aedes and Culex larva but more toxic to Aedes larvae (Tables 4 and 5). This result is also similar to the findings of [23] on the larvicidal action of Bacillus thuringiensis. However, the result was contrary to the work of [30]. Similar to the findings in this result is the report by [31] that Bacillus thuringiensis toxins showed higher toxicity to 
Aedes larvae than Culex larvae. Bacillus thuringiensis has previously been used to control different kinds of insects, such as Simuliidae (black fly), moths, butterflies, Table 1. Biochemical Characteristics of Isolated Bacillus species.

\begin{tabular}{lcccccc}
\hline Isolates & Catalase & Indole & Starch hydrolysis & Oxidase & Citrate & Probable organism \\
\hline 1 & + & - & - & - & - & Salmonella sp. \\
2 & + & - & - & - & + & Bacillus sp. \\
3 & + & - & + & - & - & Bacillus sp. \\
4 & + & - & - & - & + & Klebsiella sp. \\
5 & + & - & + & - & - & Bacillus sp. \\
6 & - & - & - & - & + & Staphylococcus sp. \\
7 & + & - & + & - & - & Bacillus sp. \\
8 & + & - & - & - & + & Bacillus sp. \\
\hline
\end{tabular}

Table 2: Toxicity Test against Culex Larvae after 4 hours and 48 hours.

\begin{tabular}{|c|c|c|c|c|c|c|}
\hline \multirow{2}{*}{ Isolates } & \multirow{2}{*}{$\begin{array}{c}3 \mathrm{hrs} \\
3\end{array}$} & \multicolumn{4}{|c|}{$48 \mathrm{hrs}$} & \multirow{2}{*}{$\begin{array}{l}\text { Percentage } \\
\text { mortality (\%) }\end{array}$} \\
\hline & & 0.5 & 1 & 2 & 3 & \\
\hline BT1 & 0 & $0.00 \pm 0.00^{b}$ & $1.00 \pm 0.00^{b}$ & $2.00 \pm 0.00^{b}$ & $3.00 \pm 0.00^{b}$ & 12 \\
\hline ВТ3 & 0 & $0.00 \pm 0.00^{b}$ & $2.00 \pm 0.00^{\mathrm{b}}$ & $4.00 \pm 0.01^{b}$ & $5.00 \pm 0.03^{\mathrm{b}}$ & 20 \\
\hline BT5 & 4 & $5.00 \pm 0.33^{\mathrm{a}}$ & $8.00 \pm 0.33^{\mathrm{a}}$ & $13.00 \pm 0.00^{\mathrm{a}}$ & $17.00 \pm 0.88^{a}$ & 68 \\
\hline BT4 & 0 & $0.00 \pm 0.00^{b}$ & $1.00 \pm 0.00^{b}$ & $3.00 \pm 0.00^{b}$ & $6.00 \pm 0.04^{\mathrm{b}}$ & 24 \\
\hline BT2 & 1 & $1.00 \pm 0.00^{b}$ & $2.00 \pm 0.00^{b}$ & $3.00 \pm 0.00^{b}$ & $4.00 \pm 0.00^{b}$ & 16 \\
\hline Control & 0 & 0 & 0 & 0 & 1 & 4 \\
\hline
\end{tabular}

Values are presented as Mean \pm SEM $(n=3)(P<0.01)$. Values within the same column carrying different super scripts are statistically different from each other.

Table 3. Toxicity Test against Aedes Larvae after 4 hours and 48 hours.

\begin{tabular}{|c|c|c|c|c|c|c|}
\hline \multirow{2}{*}{ Isolates } & \multirow{2}{*}{$\begin{array}{c}4 \mathrm{hrs} \\
3\end{array}$} & \multicolumn{4}{|c|}{$48 \mathrm{hrs}$} & \multirow[t]{2}{*}{ Percentage mortality (\%) } \\
\hline & & 0.5 & 1 & 2 & 3 & \\
\hline BT1 & 0 & $0.00 \pm 0.00^{b}$ & $1.00 \pm 0.00^{b}$ & $1.00 \pm 0.00^{c}$ & $3.00 \pm 0.11^{b}$ & 12 \\
\hline BT3 & 0 & $2.00 \pm 0.33^{b}$ & $3.00 \pm 0.33^{b}$ & $5.00 \pm 0.11^{b}$ & $5.00 \pm 0.00^{b}$ & 20 \\
\hline BT5 & 3 & $8.00 \pm 0.57^{\mathrm{a}}$ & $13.00 \pm 0.88^{\mathrm{a}}$ & $14.00 \pm 1.20^{\mathrm{a}}$ & $18.00 \pm 1.25^{a}$ & 72 \\
\hline BT4 & 2 & $1.00 \pm 0.00^{b}$ & $2.00 \pm 0.01^{b}$ & $4.00 \pm 0.11^{b}$ & $5.00 \pm 0.00^{b}$ & 20 \\
\hline BT2 & 0 & $0.00 \pm 0.00^{b}$ & $0.00 \pm 0.00^{b}$ & $1.00 \pm 0.00^{c}$ & $4.00 \pm 0.58^{b}$ & 16 \\
\hline Control & 0 & 0 & 0 & 0 & 0 & 0 \\
\hline
\end{tabular}

Values are presented as Mean \pm SEM $(n=3)(P<0.01)$. Values within the same column carrying different super scripts are statistically different from each other. 


\section{$1 \cdot 2 \cdot 3 \cdot 4 \cdot 51 \cdot 2 \cdot 3 \cdot M 9$}

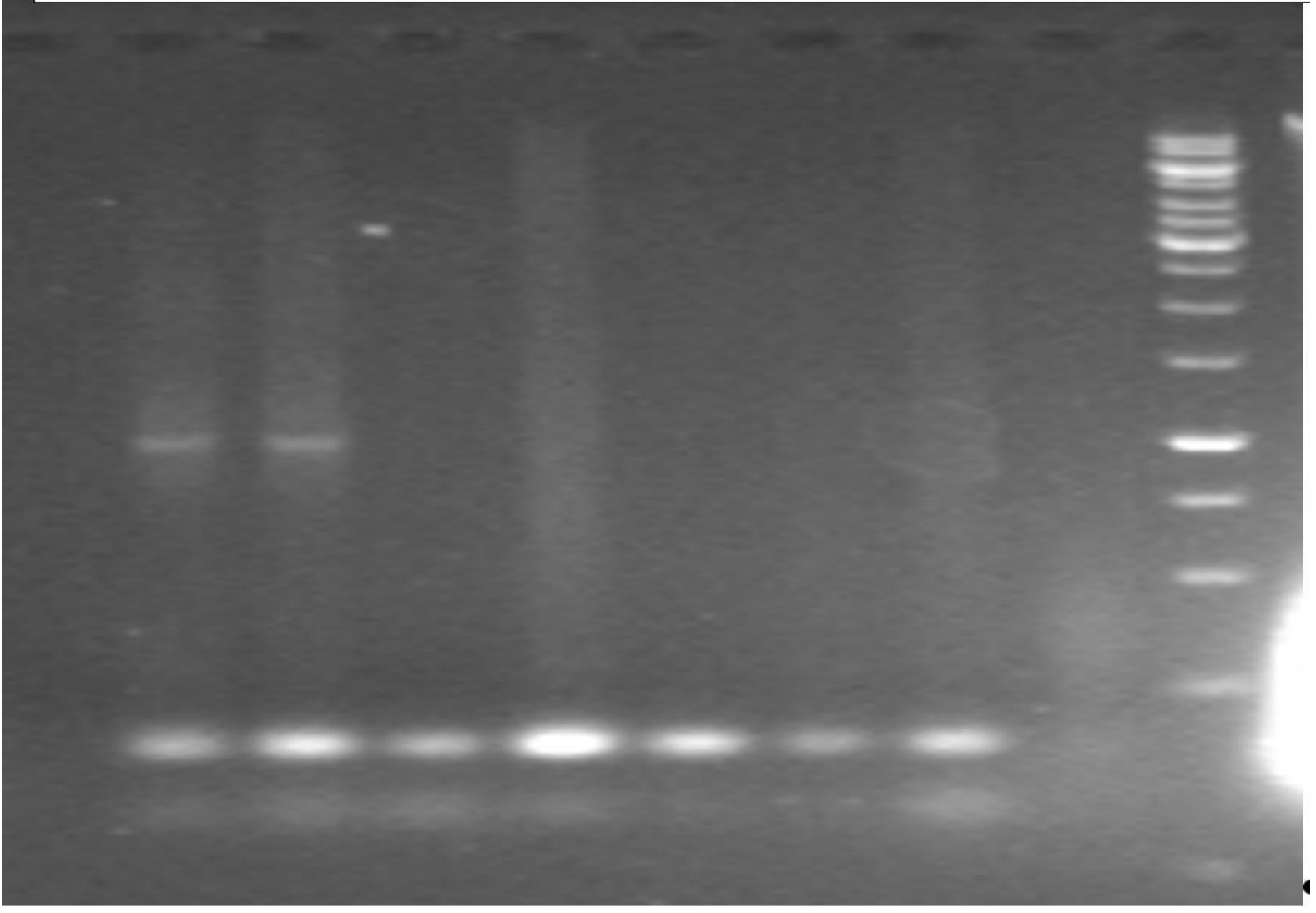

Figure 1: $M=1 \mathrm{~kb}$ DNA ladder and 1-5 (green colour) = DNA samples amplified with 16S RNA marker and 1-3 (pink colour) were optimization parts of the PCR.

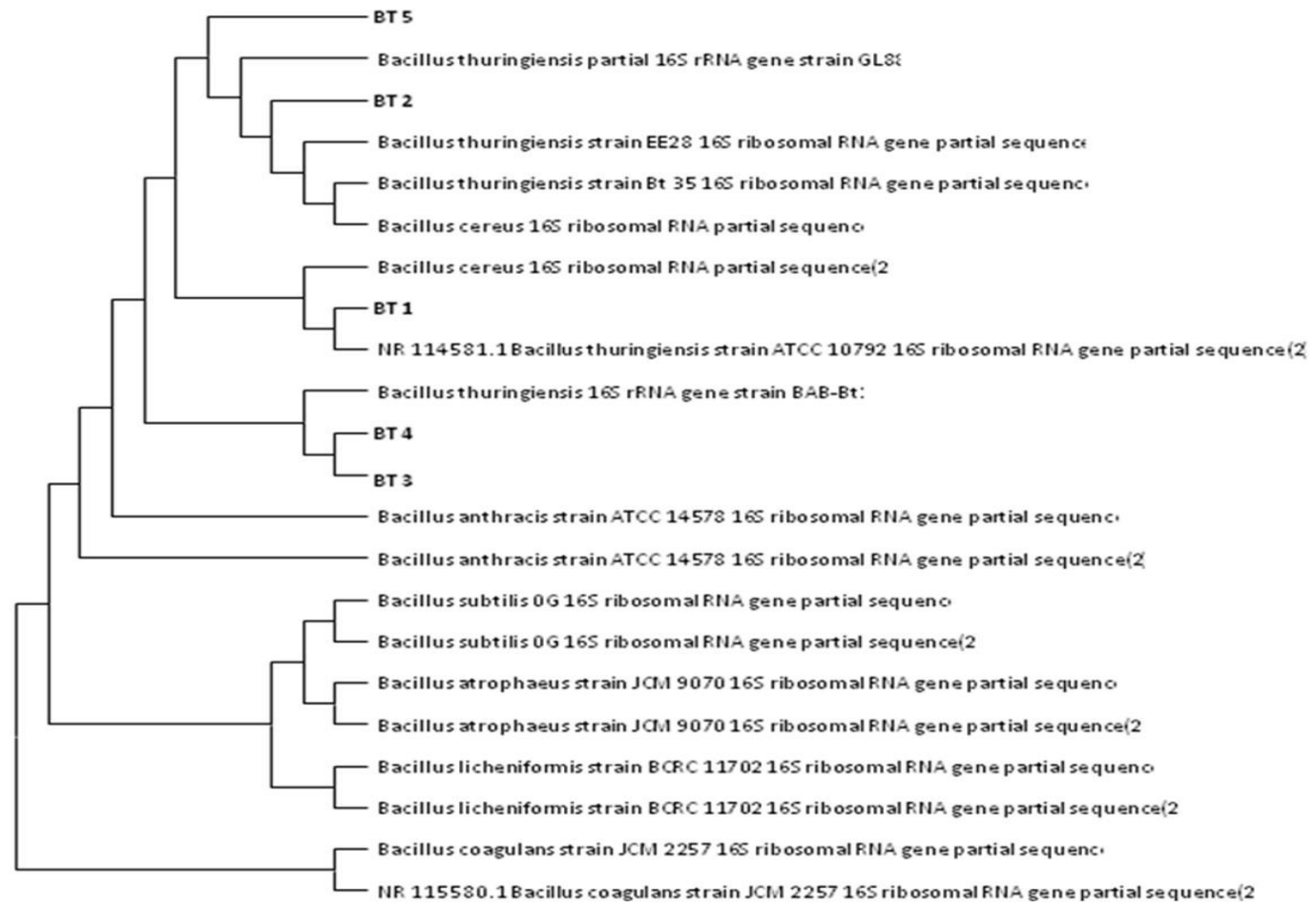

Figure 2: Phylogenetic tree constructed by Neighbor-Joining method derived from analysis of the 16S rRNA gene sequences of the isolates and related sequences obtained from NCBI (BT1= Isolate 2, BT4=Isolate 7 , $\mathrm{BT} 2=$ Isolate $8, \mathrm{BT} 5=$ Isolate $5, \mathrm{BT} 3=$ Isolate 3 ) 
Isolate BT5 was the most effective agent against the larvae. This was showed by the presence of Cry protein known to be peculiar to $B$. thuringiensis, as evidenced by the genetic analysis.

Table 4: Occurrence of crystal genes among Bacillus thuringiensis isolates.

\begin{tabular}{|l|c|c|c|c|c|c|}
\hline $\begin{array}{l}\text { Cry } \\
\text { genes }\end{array}$ & BT5 & BT3 & BT4 & BT1 & BT2 & $\begin{array}{c}\text { Occurrence } \\
(\%)\end{array}$ \\
\hline Cry1 & + & + & + & + & + & 100 \\
\hline Cry2 & + & + & + & + & - & 80 \\
\hline Cry3 & + & + & + & - & - & 60 \\
\hline Cry4 & + & + & + & - & - & 60 \\
\hline Cry7 & - & - & + & - & - & 20 \\
\hline Cry9 & - & - & - & + & - & 20 \\
\hline Cry11 & + & + & + & + & + & 100 \\
\hline
\end{tabular}

Molecular characterization confirms the isolates to be Bacillus thuringiensis strains. Furthermore, the nucleotide sequences obtained from the amplification products showed significantly more similarities to Bacillus thuringiensis than known 16S rDNA sequences in the NCB database. The PCR technique has been commonly used to identify crystal genes and predict the insecticidal activity of Bacillus thuringiensis strains $[2,4,32]$. The highest number and diversity of toxins were observed for the strains in BT5, BT3, BT4, BT1, BT2. This confirms that native strains showed a wide genetic diversity based on insecticidal gene contents, and each isolate contained different insecticidal genes [33]. Also, from the phylogenetic tree constructed (Figure 2), BT 4 and BT3 are more closely related. Therefore, there is a high probability of BT 4 and BT 3 being the same species but having different strains or exact origins.

The Bacillus thuringiensis isolated possessed the desired band sizes that showed that this bacterium harbors crystal 1 and 2 genes at 100 and $80 \%$ level of occurrence, respectively (Table 4). The crystal gene found naturally in Bacillus thuringiensis belongs to the crystal 1 gene group [33].

Wang et al. (2003) have reported that Cry 1 genes were the most frequent in their collections. Similarly, in this study, isolates containing Cry 1gene were the most abundant group with a frequency of occurrence of $100 \%$. Many studies have reported that Cry 1 and 2 genes were most often present together $[23,31,33]$. Also, [33] discovered that strains containing Cry 1 type genes were found at the same frequency as strains harboring Cry 2 genes. Cry 7 and 9 only occur in $20 \%$ of the isolates, indicating that Cry 7 and 9 genes are less abundant. Cry 3 and 4 genes occur in $60 \%$, while 11 was found in $40 \%$ of the isolates. This finding is similar to the reports of $[25,31]$. The presence of the Cry gene has contributed immensely to the insecticidal activity reported in this research $[2,4]$.

Besides the Cry toxins, Bacillus thuringiensis contains other virulence factors $[2,10]$ such as alpha and beta exotoxins, hemolysins, enterotoxins, chitinases, and phospholipases [33]. However, the concentration and activities of these substances vary, and the precise contribution of each is not discovered yet, hindering the determination of the real toxic spectrum of an isolate that produces more than one type of toxin [31].

There usually was a correlation between bioassay results and Cry gene profiles. However, some Cry gene-containing strains, primarily BT 1 and BT 2, exhibited low toxicity. However, the insecticidal activity of Bacillus thuringiensis is not always a function of the possession of the Cry gene. Some other virulent factors or structural genes, including spore interaction with Cry proteins, other soluble toxins, and the possible presence of undetected Cry proteins, may also play a significant role in their toxicity [33]. The target larvae were sensitive to the $B$. thuringiensis isolates. This may be due to various factors like genetics, amount of toxin ingested, degree of larval midgut damage, and finally, the mode of action of the toxin. A previous study reported that upon ingestion of the bacterium by the larvae, the toxins bind synergistically to specific receptors in larval midgut resulting in the formation of pores in the epithelial cell membrane leading to the inability to feed and subsequently the death of larvae [2].

This study is limited to a laboratory trial since no field trial has been carried out. Its toxicity was also limited to Culex and Aedes larvae.

\section{Conclusion}

The five isolates identified as Bacillus thuringiensis demonstrated larvicidal activity against the mosquito larvae tested at various levels, with isolate BT5 being the most effective. In addition, the molecular analysis further buttresses the fact that the isolates 
were Bacillus thuringiensis. Hence, the isolated Bacillus thuringiensis can be used as biopesticides or in the formulation of biopesticides to control Aedes and Culex mosquitoes instead of chemical pesticides that are harmful to humans and the environmental health.

\section{ACKNOWLEDGMENTS}

Declaration of conflicting interest: The author(s) declare no potential conflicts of interest concerning this article's research, authorship, and/or publication.

Financial disclosure: No financial support was received for this study

\section{REFERENCES}

1. Rajesh K, Dhanasekaran D, Tyagi BK. Mosquito Survey and Larvicidal Activity of Actinobacterial Isolates against Culex larvae (Diptera: Culicidae). J Saud Soc Agric Sci 2015; 14:116122.

2. Rajendran J, Subramanian N, Velu RK. Larvicidal Activity of Bacillus thuringiensis Isolated from Cotton Rhizosphere Soil against Anopheles Mosquito Larvae (Culicidae). Asian J Pham Clin Res 2018; 11(9): 456-462.

3. Etim LB. In vitro evaluation of Bacillus thuringiensis Larvicide Effect on Anopheles subpictus Larvae. Inter J Mosq Res 2019; 6(3): 45-49.

4. El-kersh TA, Ahmed AM, Al-sheikh YA, Tripet F, Ibrahim MS, Metwalli AAM. Isolation and Characterization of Native Bacillus thuringiensis Strains from Saudi Arabia with Enhanced Larvicidal Toxicity against the Mosquito Vector Anopheles gambiae (s.I.) Parasit \& Vector 2016; 9:647 Doi:10.1186/s13071-016-1922-6.

5. Gill HK, Garg H. Pesticides: Environmental Impacts and Management Strategies. In: Soloneski S, editor. Pesticides-Toxic Aspects. New York: In Tech Open 2014;187-230.

6. Cuervo-Parra, JA, Cortés, TR, Ramirez-Lepe, M. Mosquito-Borne Diseases, Pesticides used for Mosquito Control, and Development of Resistance to Insecticides. In: Trdan S, editor. Insec Res New York: In Tech Open; 2016; 112 134.

7. Suryadi BF, Yanuwiadi B, Ardyati T, Suharjono $\mathrm{T}$. Isolation of Bacillus sphaericus from Lombok Island, Indonesia, and Their Toxicity against Anopheles aconitus. Inter J Mic 2015; 854709, http://dx.doi.org/10.1155/2015/854709

8. Popp J, Pető K, Nagy J. Pesticide Productivity and Food Security. A review: Agro Sustain Dev 2013; 33: 243-55.

9. Ravensberg WJ. Commercialization of microbes: Present Situation and Future Prospects. In: Principles of Plant-Microbe Interactions. Berlin: Springer 2015; 309-17.
10. De Maagd RA. Bacillus thuringiensis- Based Products for Insect Pest Control. Principles of Plant-Microbe Interactions. Springer Inter Switz 2015; 151 (76): 185-192.

11. Thaphan P, Keawsompong S, Chanpaisaeng J. Isolation, Toxicity and Detection of Cry Gene in Bacillus thuringiensis Isolates in Krabi province, Thailand. Songklanakarin J Sci Techol 2008; 30(3): 597- 601 .

12. Cheesebrough M. District Laboratory Practice in Tropical Countries. Part2. Low Price Edition. Cambridge University Press, London; 2006.

13. Fawole MO, Oso BA. Laboratory Manual in Microbiology. Revised Edition. New Spectrum Books Publisher, Ibadan, Nigeria; 2007.

14. Neil L, Isolation of a Bacillus thuringiensis Strain from South African Soils and the Characterization of its Cry Gene Sequence. School of Molecular and Cell Biology, University of the Witwatersrand, Johannesburg; 2006.

15. Dela C, lan NB, Baustista JR, Teres FG. Isolation and Identification of Bacillus thuringiensis from Harpaphe Haydeniana and its Entomotoxic Evaluation against Aedes and Culex Larvae. Int. Res. J Bio Sci 2015; 4(3): 1-5.

16. Abarshi MM, Mohammed IU, Wasswa $P$, et al. Optimization of Diagnostic RT-PCR Protocols and Sampling Procedures for the Reliable and Cost-Effective Detection of Cassava Brown Streak Virus. J Virol Meth 2010; 163(38): 353359.

17. Aramideh S, Shahram M, Abbas $H$, et al. Isolation, Toxicity and Detection of Crystal Genes of Bacillus thuringiensis Isolates from West- Azerbaijan Province, Iran. J Ento and Zoo Stud 2016; 4(6): 111-116.

18. Ntuli V, Mekibib SB, Molabatsi N, Makotobo M, Chatanga P, Asita OA. Microbial and Physiological Characteristics of Maize and Wheat Flour from a Milling Company, Lesotho. Inter J Food Safet 2013; 15(1): 11-19.

19. Lee DH, Cha IH, Woo DS, Ohba M. Microbial Ecology of Bacillus thuringiensis: Fecal Populations Recovered from Wildlife in Korea. Can J Mic 2003; 49(8): 465-471.

20. Ibarra JE, De Rincón C, Ordúz S, et al. Diversity of Bacillus thuringiensis Strains from Latin America with Insecticidal Activity against Different Mosquito Species. Appl Envi Mic 2003; 69(9): 5269-5274.

21. Joelma $S$, Valéria CS, Eleilza L, Ricardo AP, Wanderli PT. Isolation of Bacillus thuringiensis from the State of Amazonas, in Brazil, and Screening against Aedes aegypti (Diptera, Culicidae). Revi Brasil de Entom 2015; 59 (1): 16.

22. Kassogué $A$, Maïga, $K$, Traoré $D$, et al. Isolation and Characterization of Bacillus thuringiensis (Ernst Berliner) Strains Indigenous to Agricultural Soils of Mali. Afri J Agri Res 2015; 10(28): 2748-2755. 
23. Hongyu Z, Ziniu Y, Wangxi D. Isolation, Distribution and Toxicity of Bacillus thuringiensis from Warehouses in China. Crop Protection 2000; 19: 449-454.

24. Apaydin Z, Yenidunya AF, Harsa S, Gunes H. Isolation and Characterization of Bacillus thuringiensis Strains from Different Grain Habitats in Turkey. World J Mic and Bio 2005; 21: 285-292.

25. Sarrafzadeh MH. Nutritional Requirements of Bacillus thuringiensis During Different Phases of Growth, Sporulation and Germination Evaluated by Plackett-Burman Method. Iran J Chem Chem Eng Res Note 2012; 31(4).

26. Polanczyk RA, Silva RFP, Fiuza LM. Isolamento de Bacillus thuringiensis Berliner a partir de amostras de solos esuapatogenicidade para Spodoptera frugiperda (J. E. Smith) (Lepidoptera: Noctuidae). Rev Bra Agro Sci 2004; 10 (7): 209-214.

27. Saadaoui I, Rouis S, Jaoua SA new Tunisian strain of Bacillus thuringiensis krustaki Having High Insecticidal Activity and $\delta$-endotoxin. Arch Micro 2009; 191(142): 341-348.

28. Bravo A, Likitvivatanavong S, Gill, S Sober'on M. Bacillus thuringiensis: A Story of a Successful Bioinsecticide. Insect Biochem Mol Bio 2011; 41(35): 423-424.

29. Raymond B, Johnston PR, Nielsen-LeRoux C, Lereclus D, Crickmore N. Bacillus thuringiensis: an Important Pathogen. Trends Micro 2010; 18(5): 189-194.

30. Fakruddin MD, Nishat S, Monsur MA, Rasheed N. Protein Profiling of Bacillus thuringiensis Isolated from Agro- Forest Soil in Bangladesh. J Mol Bio Biotech 2012; 20(4): 139 -145.

31. Praça LB, Batista AC, Martins ES, et al. Estirpes de Bacillus thuringiensise fetivas contra insetos das ordens Lepidoptera.Coleoptera e Diptera. Pesqui. Agropecu. Bras 2004; 39 (5): 11-16.

32. Mohd AFA, Oscar A, Marwan M, Rebecca JM, Michael JA, Donald HD. Introduction of Culex Toxicity into Bacillus thuringiensis Cry4Ba by Protein Engineering. Appl Environ Micro 2003; 69(9): 5343- 5353.

33. Eleny $\mathrm{P}$, Beatriz $\mathrm{T}$, Erica $\mathrm{M}$, et al. Comparative Toxicity of Bacillus thuringiensis Berliner Strains to Larvae of Simuliidae (Insecta: Diptera). Bac Thu Res 2013; 4 (2): 8-18. 